\title{
Key elements to enable systemic innovation in construction firms
}

\author{
Elementos-chave para possibilitar a inovação sistêmica \\ em empresas construtoras
}

\begin{abstract}
Carolina Mendonça de Moraes Duarte
Flávio Augusto Picchi iD
Abstract

$\mathbf{T}$

he construction industry is generally known to be resistive to change and reluctant to embrace new technologies. Innovation, which might be described as the successful exploitation of new ideas, is usually seen as the key to unlocking the industry's potential. Although there is no doubt that some progress has been made, construction innovation still occurs in a random manner, not as a systemic and managed process. Regardless of the growing number of studies on construction innovation management, there is still a lack of research that identify, compile, classify, and summarize the innovation enablers in construction. Thus, based on a Systematic Literature Review (SLR), this paper aims to provide a holistic understanding of the key elements that enable systemic innovation in construction from a firm-level perspective. The review incorporated data from 38 articles to establish a set of 15 enablers of innovation in construction firms, such as innovation culture, external collaboration (open innovation), knowledge management, and upper management support. The enablers were classified into five different aspects of innovation management: strategic, organizational, human, processual, and financial. The review also sought to identify practices, routines, methods, or tools that can be adopted to increase innovation activity in construction firms.
\end{abstract}

Keywords: Innovation. Systemic innovation. Innovation management. Construction. Systematic literature review.

\section{Resumo}

Sabe-se que a indústria da construção é resistente a mudanças e relutante em adotar novas tecnologias. A inovação, que pode ser descrita como a exploração bem-sucedida de novas ideias, geralmente é vista como a chave para destravar o potencial do setor. Embora não haja dúvida de que houve algum progresso, a inovação na construção ainda ocorre de maneira aleatória, não como um processo sistêmico e gerenciado. Apesar do número crescente de estudos sobre gestão da inovação na construção, ainda não foram realizadas pesquisas para identificar, compilar, classificar e sintetizar os facilitadores da inovação na construção. Assim, com base em uma Revisão Sistemática da Literatura (RSL), este artigo objetiva fornecer uma

${ }^{1,2}$ Carolina Mendonça de Moraes Duarte

1 Universidade Estadual de Campinas ${ }^{2}$ Instituto Federal de Alagoas Maceió - AL - Brasil

${ }^{3,4}$ Flávio Augusto Picchi 3Universidade Estadual de Campinas ${ }^{4}$ Lean Institute Brasil São Paulo - SP - Brasil

Recebido em 28/07/20 Aceito em 01/04/21 compreensão holística dos elementos-chave que possibilitam a inovação sistêmica na construção a partir de uma perspectiva intrafirma. A revisão incorporou dados de 38 artigos para estabelecer um conjunto de 15 facilitadores da inovação em construtoras, como cultura de inovação, colaboração externa (inovação aberta), gestão do conhecimento e suporte da alta gerência. Os facilitadores foram classificados em cinco aspectos diferentes da gestão da inovação: estratégico, organizacional, humano, processual e financeiro. A revisão também procurou identificar práticas, rotinas, métodos ou ferramentas que podem ser adotadas para aumentar a atividade de inovação nas empresas de construção.

Palavras-chave: Inovação. Inovação sistêmica. Gestão da Inovação. Construção . Revisão sistemática da literatura. 


\section{Introduction}

Innovation has become an increasingly vital component of competitiveness and development at national, regional, and organizational levels. The topic has been researched in many academic disciplines, including business administration, public management, economics, science, and technology, using diverse methodologies and levels of analysis (TIDD; BESSANT, 2013). However, research on construction innovation is still scarce and based on the body of knowledge of other industries (XUE et al., 2014; ORSTAVIK; DAINTY; ABBOTT, 2015).

Some authors address the barriers and drivers of innovation in civil construction in their research, and both are basically discussed at two levels: organizational and institutional (MANLEY; MCFALLAN, 2006; BOSSINK, 2004; SUPRUN; STEWART, 2015). The nomadic character of the industry, the unique nature of the construction projects, the complex multidisciplinary process of designing, the low qualification of the workforce, and the dependence on the other industrial sectors are still major obstacles to the adoption of innovations. The inherent conservatism in the construction industry is also an obstacle to innovation, which requires a favorable culture, where its leaders encourage the taking of controlled risks, invest time and money in the construction of new paths (SEADEN; MANSEAU, 2001; HARTMANN, 2006; SOARES et al., 2016).

Despite the above, it is undeniable that technological advances in construction have occurred in recent years. Slowly but surely, construction firms are recognizing the need for innovation, whether through the adoption of new construction systems, the use of new materials and equipment, the use of information technology tools, or even the development of new business models. However, investing in innovation in an isolated and random way does not guarantee a sustainable competitive advantage (MIOZZO; DEWICK, 2002; VOLBERDA; BOSCH; HEIJ, 2013). Innovation does not depend on impulsive actions in order to solve a specific problem or put into practice a brilliant idea; on the contrary, it can be systematized (YEPES et al., 2016). For companies to be able to turn innovation into a discipline, it is necessary to resort to a structured approach through innovation management.

Innovation management seeks to structure, from a strategic perspective, organizational resources, processes, tools and practices in a systemic way, so that innovation is not something spontaneous or random in the company, but an organized, growing and permanent process (QUADROS, 2008). It facilitates the incorporation of new ideas as well as increases the ability to acquire, develop, and use new knowledge (CORREA; YEPES; PELLICER, 2007). Successful innovation outcomes are achieved through an appropriate innovation focus that is responsive to contextual factors, realized by organizational capabilities and chanelled through effective and efficient innovation processes (BARRETT; SEXTON; LEE, 2008).

In the past few years, innovation management has gained increased popularity in both academic and practical research. Different models for managing innovation have emerged from literature, reflecting the plurality of approaches - a consequence of the topic's multidisciplinarity (SILVA; BAGNO; SALERNO, 2013). These models incorporate several concepts, practices, and methodologies that enable innovation, such as Knowledge Management, Technology Watch, Idea Management, Open Innovation, and Organizational Climate. Although innovation management is not widely explored in the construction literature, some researchers have attempted to identify elements that enable systemic innovation in construction firms. For instance, Davidson (2001) has studied how Technology Watch can facilitate the adoption of innovation in the construction sector. The role of leadership in fostering an innovation climate in construction firms was explored by Chan, Liu and Fellows (2014). Toole, Hallowell and Chinowsky (2013) have identified a set of characteristics that promote innovation in construction organizations. In addition to these studies, others have also identified innovation enablers in construction under different approaches. This information is scattered, and, to the best of the researchers' knowledge, there has never been an attempt to identify, compile, classify, and summarize these enablers.

Hence, this study seeks to provide a holistic understanding of the key elements that enable systemic innovation in construction from a firm-level perspective, through a Systematic Literature Review (SLR). These innovation enablers were identified and classified into different aspects of innovation management. Besides this introduction, the paper is structured into the following main sections: the second section presents the aim of the study and the research questions, followed by a section describing the method adopted. Results are presented and discussed in the fourth section, where the open issues in systemic innovation in construction firms are addressed. Finally, conclusions are presented in the last section of the study.

386 Duarte, C. M. de M.; Picchi, F. A. 


\section{Aim and research question}

This paper builds on emerging research into innovation management in the construction industry. It starts from the hypothesis that the continuous and permanent development of innovations in construction firms is only possible when innovation is viewed through strategic lens. With this in mind, the following research questions were addressed:

(a) How can systemic innovation be enabled in construction firms? and

(b) Which practices, routines, methods, or tools can be adopted to increase innovation activity in construction firms?

The aim of the study is to identify, compile, classify, and summarize the key elements to enable systemic innovation in construction firms. It is expected to contribute to the body of knowledge by bringing a reference for construction firms that intend to innovate continuously and systemically.

\section{Method}

Given the aim of this study, the authors adopted a Systematic Literature Review (SLR), which is a means of identifying, selecting, critically appraising, and interpreting the results of relevant primary studies on a specific research question or topic. It differs from a traditional narrative review by adopting a replicable, scientific, and transparent process to minimize bias through exhaustive literature searches (TRANFIELD; DENYER; SMART, 2003). Furthermore, SLRs allow new developments based on primary studies already published, since the synthesis of this set may provide new inferences, that research, individually, is not able to offer (MUIANGA; GRANJA; RUIZ, 2015).

Before undertaking the SLR itself, three preliminary stages were taken in this research:

(a) establishment of conceptual boundaries;

(b) definition of the aim of the study; and

(c) definition of the research questions.

The first stage was essential to define the scope of the review and assist researchers in adapting the aim and the research question based on the information available on the topic (KITCHENHAM; CHARTERS, 2007; MORANDI; CAMARGO, 2015). To this end, an exploratory review on innovation management in the construction industry was conducted, making it possible to identify key concepts and verify the absence of previous SLRs covering the topic. It is important to note that this stage was carried out in the context of the first author's doctoral thesis.

From the establishment of the conceptual boundaries, the objective and the research questions were defined. Then, the SLR was structured and conducted, as detailed later in this section. Figure 1 shows the study design, which also includes a final stage where the results are presented and discussed.

\section{Systematic literature review}

Although there is no single procedure for conducting a SLR, some stages and activities are common to most methods, such as planning, searching, selection and reporting. Kitchenham and Charters (2007), based on systematic review process proposed in different sources, summarized the stages into three main phases:
(a) planning the review;
(b) conducting the review; and
(c) reporting the review. 
Figure 1 - Study Design

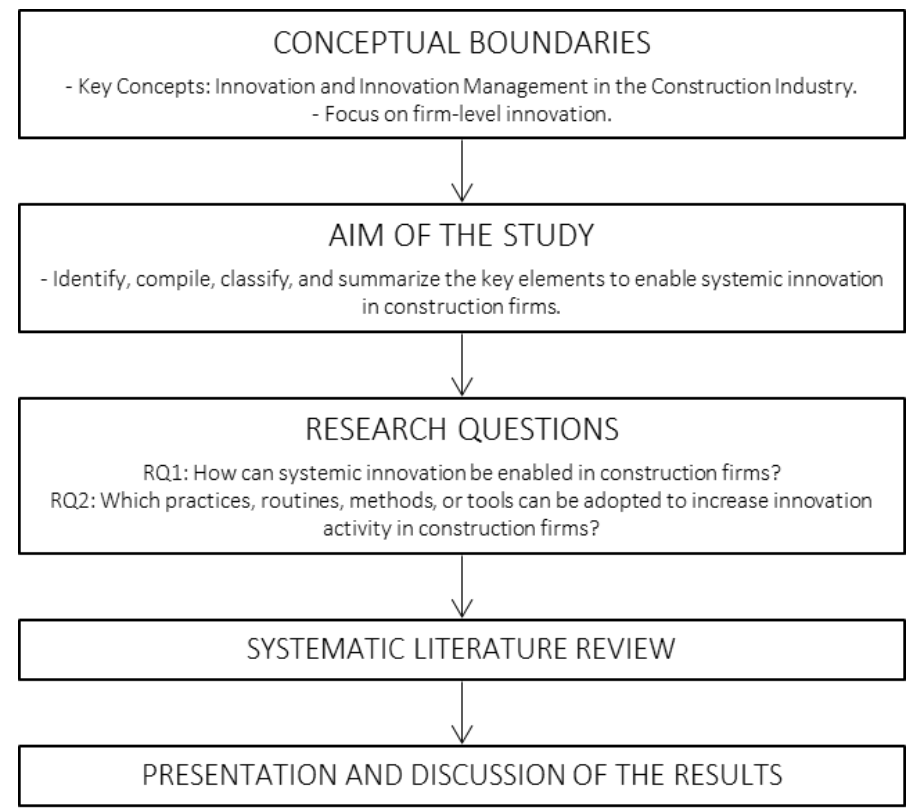

Likewise, Morandi and Camargo (2015) propose a method that seeks to compile and expand the steps described in four other studies, which are:

definition of the central theme and conceptual framework;

(a) teamwork selection;

(b) search strategy;

(c) search, eligibility and coding;

(d) quality assessment;

(e) summary of results; and

(f) presentation of the study.

This SLR was carried out according to the three phases proposed by Kitchenham and Charters (2007) and also considered the guidelines presented by Morandi and Camargo (2015), as described in Figure 2.

\section{Planning the review}

Systematic reviews can vary in many dimensions, such as extent, breadth, depth, time and resources employed. They can be more extensive and cover a larger scope or be less extensive and focus on a specific approach (GOUGH; THOMAS, 2012). Given the study's exploratory nature, open research questions were set, leading to a configurative review, which is usually answered with qualitative data, extracted from more heterogeneous primary studies, analyzed, and interpreted to generate and explore the theory (MORANDI; CAMARGO, 2015).

Then, a protocol was developed to define the search strategy for primary studies, which included:

(a) selection of search sources;

(b) definition of search terms and formulation of search strings; and

(c) inclusion and exclusion criteria.

\section{Selection of search sources}

The selection of suitable search sources is essential for the outcome of SLRs. This step was performed based on the criteria proposed by Gusenbauer and Haddaway (2020), which examined 28 academic search systems and found that only 14 of them are well-suited to evidence synthesis in the form of systematic reviews. Among the 
search systems suggested in the study mentioned above, only 4 covered the specific area of this research. After testing all of them, Web of Science and Scopus, two world-leading and competing citation databases, were selected.

\section{Definition of search terms and formulation of search string}

Before the actual search for the papers, some initial searches were undertaken. These searches retrieved some relevant documents to determine keywords and optimal terms. Since innovation is a broad and multidisciplinary concept, approached from different perspectives, it was necessary to establish a delimitation of the term. Although it refers to the process, as mentioned in the previous section, the term innovation can also refer to this process's outcome (new products, new services, new business models, new organizational structures, etc.). This semantic duality is frequently questioned (CROSSAN; APAYDIN, 2009; QUINTANE et al., 2011) but there is still no consensus on the ideal terminology to distinguish the two meanings of the term. Hence, the researchers realized that using the term innovation in an isolated way would return a vast number of publications unrelated to the research question, mainly studies that address only technical aspects of the development of an innovation. It was then decided to use the terms "systemic innovation", "innovation management", "management of innovation", "managing innovation" and "innovation process management". The term "construction" was also used to emphasize the context of the research. Table 1 shows the search string, which is joined by Boolean operators "OR" and "AND".

\section{Inclusion and exclusion criteria}

The inclusion and exclusion criteria were set out to ensure that the boundaries of the review question were clearly defined. For this review, no date restrictions were applied, and only articles in English, Spanish or Portuguese language were considered. It was limited to a search for full-text online sources that were academic journal articles or conference papers. No restrictions on the type of document were made. Since not all relevant studies may be included in the databases, and even if they are, they may not contain the search terms in the title, abstract, or keyword, it is important to establish criteria to identify additional papers. In this review, a backward snowballing approach was performed, which refers to using a paper's reference list to identify additional publications.

\section{Conducting the review}

In both selected databases, the search was carried out by topic (title, abstract, keywords). Based on the search criteria previously established, the initial search returned 368 publications. A four-step-process was used to refine the results. Duplicate publications were excluded from the search, and consequently, 242 articles remained. At the next step, the article titles and abstracts were reviewed to determine whether the paper addressed the topic at hand, and 34 papers were selected accordingly. Then, the snowball sampling approach was used to identify relevant papers that were not returned by the search. This step required special attention from the researchers to minimize the occurrence of bias. Not only the title of the paper was analyzed for potential inclusion, but also the publication venue and authors, as recommended in Wohlin (2014). If it were a candidate for inclusion, the abstract was read in detail to confirm its relevance to the research. An additional 14 papers were selected through this step.

Of the 48 papers eligible for a full assessment, 07 were not available in full-text. The remaining studies were analyzed in depth to identify elements to answer the research question. This process led to the final inclusion of 38 articles for this SLR. The review process is illustrated in Figure 3.

In the next stage, data from the 38 studies were extracted and synthesized for the purpose of this SLR. A data extraction form was designed in MS Excel to extract relevant data in a consistent manner to answer the review questions. The articles were first coded according to bibliographic, methodological, and contextual characteristics. Table 2 describes what information was extracted from the studies.

The synthesis process presupposes the combination of interconnected results to generate new knowledge that did not exist in the original primary studies (MORANDI; CAMARGO, 2015). It is necessary to analyze and organize the available data to identify patterns between them. Data synthesis was achieved using content analysis, an established method of research used to condense text into fewer content-related categories (DURIAU; REGER; PFARRER, 2007; KRIPPENDORFF, 2012). Content analysis was used to identify and categorize elements that enable systemic innovation in construction firms, including their associated practices, routines, methods, or tools. Based on the analysis, 15 innovation enablers were identified and 
classified into 05 different categories, referred to in this study as "aspects of innovation management", which will be properly presented and discussed ahead.

Figure 2 - Structure of the systematic literature review

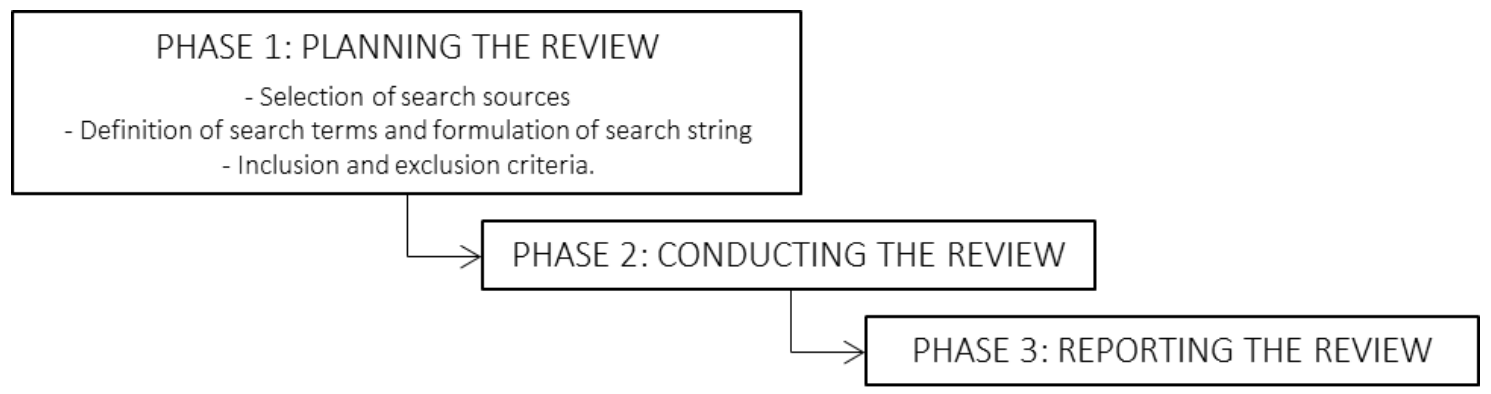

Table 1 - Search terms and search string

\begin{tabular}{|c|c|}
\hline TERMS & STRING \\
\hline systemic innovation, innovation \\
$\begin{array}{c}\text { management, management of innovation, } \\
\text { managing innovation, innovation process } \\
\text { management, construction }\end{array}$ & ("innovation management" OR "management of \\
innovation" OR "managing innovation" OR \\
"innovation process management" OR "systemic \\
innovation") AND ("construction")
\end{tabular}

Figure 3 - Flow diagram illustrating the review process

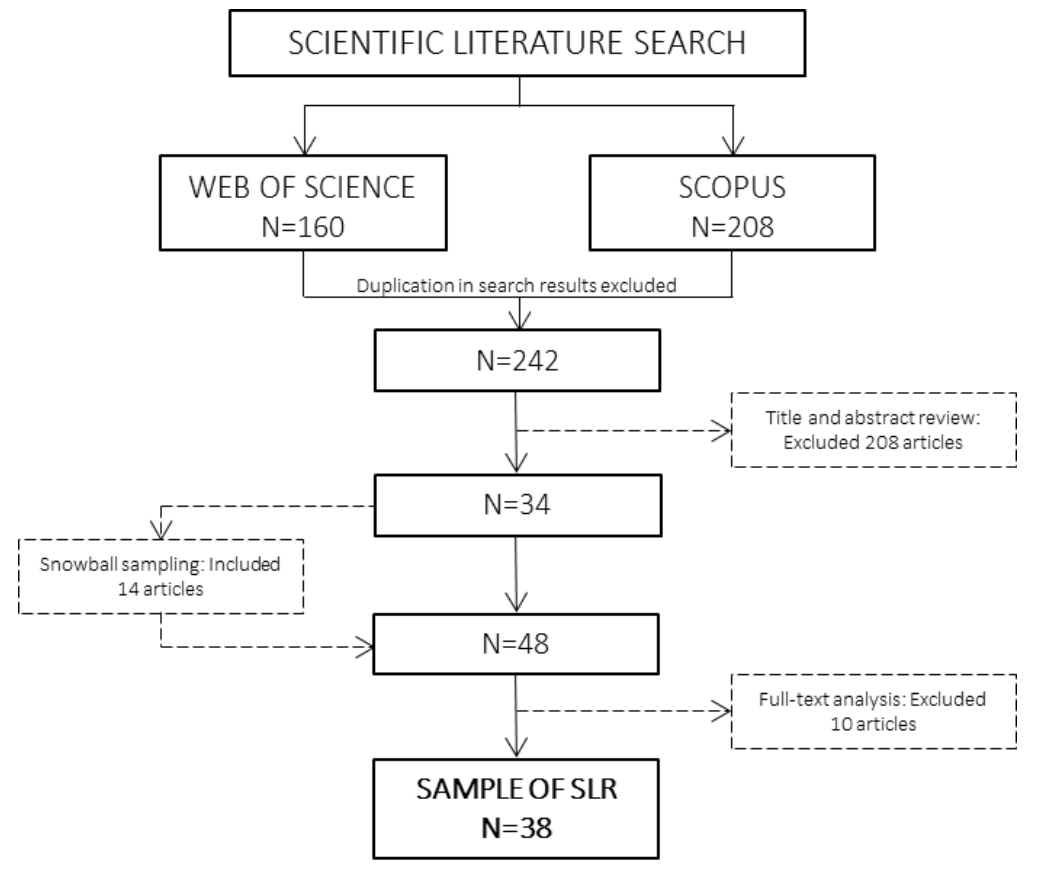

Table 2 - Information extracted from the studies

\begin{tabular}{|c|c|c|}
\hline BIBLIOGRAPHIC & METHODOLOGICAL & CONTEXTUAL \\
\hline $\begin{array}{c}\text { Year } \\
\text { Source of publication } \\
1^{\text {st }} \text { author country of origin } \\
\text { Authors' affiliation }\end{array}$ & $\begin{array}{l}\text { Research objective } \\
\text { Study type }\end{array}$ & $\begin{array}{l}\text { Types of innovation } \\
\text { Boundaries of research } \\
\text { (focus and sector) }\end{array}$ \\
\hline
\end{tabular}




\section{Reporting the review}

In the third and last stage of the SLR, the descriptive analysis of the literature is presented. The bibliometric analysis aims to verify the characteristics of the publications selected in the previous phase. Some data were summarized in graphs and tables to better illustrate the results. As Figure 4 shows, the first studies investigating the topic under review were published in the late 1980s. Both are the seminal studies by Tatum (1987, 1989), which remain relevant references for construction innovation research. The articles identified have been spaced out over the years. Still, there is a notable increase in publications from 2010 on, which is, to a certain extent expected, since the theme of innovation has grabbed the attention of academics and practitioners in the last years.

Of the 38 articles included in this review, only 02 are publications from conferences or congresses. The remaining are articles published in 20 different journals, as listed in Table 3. The journals that have published most frequently on the topic include the Construction Management and Economics, Journal of Construction Engineering and Management, Journal of Management in Engineering, and Building Research and Information. About $50 \%$ of the selected articles were published in the journals above mentioned. The relatively large number of sources and the different scopes of the journals reflect the topic's multidisciplinary range.

Of the 38 articles, as many as 35 scholars have been first authors and 28 scholars have contributed as co-authors. The most pronounced authors are the researchers Eugenio Pellicer, Víctor Yepes e Christian L. Correa, from Universitat Politècnica de València e Universidad Catolica del Maule, who together published 05 of the 38 articles selected in this review. Due to these authors' publications, Spain stands out as one of the countries with the most significant number of articles, behind only the United Kingdom and the United States, as shown in Figure 5. It is noteworthy that no articles from Brazil were identified in the sample, which suggests that local researchers have not yet explored the theme of construction innovation process in the particular approach of this RSL.

In addition to bibliometric information, the researchers sought to extract from the publications some methodological and contextual characteristics. The articles' objectives were mapped and compared to better understand the extent to which studies could contribute to the answer to the research question. The type of research was also verified, whether theoretical or empirical. From the selected sample, 31 publications are empirical articles, the vast majority of which are case studies in construction companies. Some of these empirical articles use established theoretical frameworks and distinguish between the levels of analysis when investigating construction innovation. As not all studies made such a distinction, these authors sought to identify the boundaries of each research. The vast majority carried out their an alysis considering the firmlevel, 26 in total. Another 08 studies expand their limits to understand how innovation occurs in an interinstitutional way, at an industry-level. The remaining studies go deeper into the analysis of how innovation processes occur at the project-level. It is worth noting that, although this review focuses on the elements to enable systemic innovation at a firm-level, studies aimed at industry-level bring a broader view of construction innovation, contributing mainly in the perspective of collaboration between the construct firms and external agents. Not all publications reviewed specify which primary sector of the construction industry the research encompasses. Only a single article is aimed explicitly at Building Construction and another five at Heavy or Infrastructure Construction.

\section{Figure 4 - Number of annual publications}

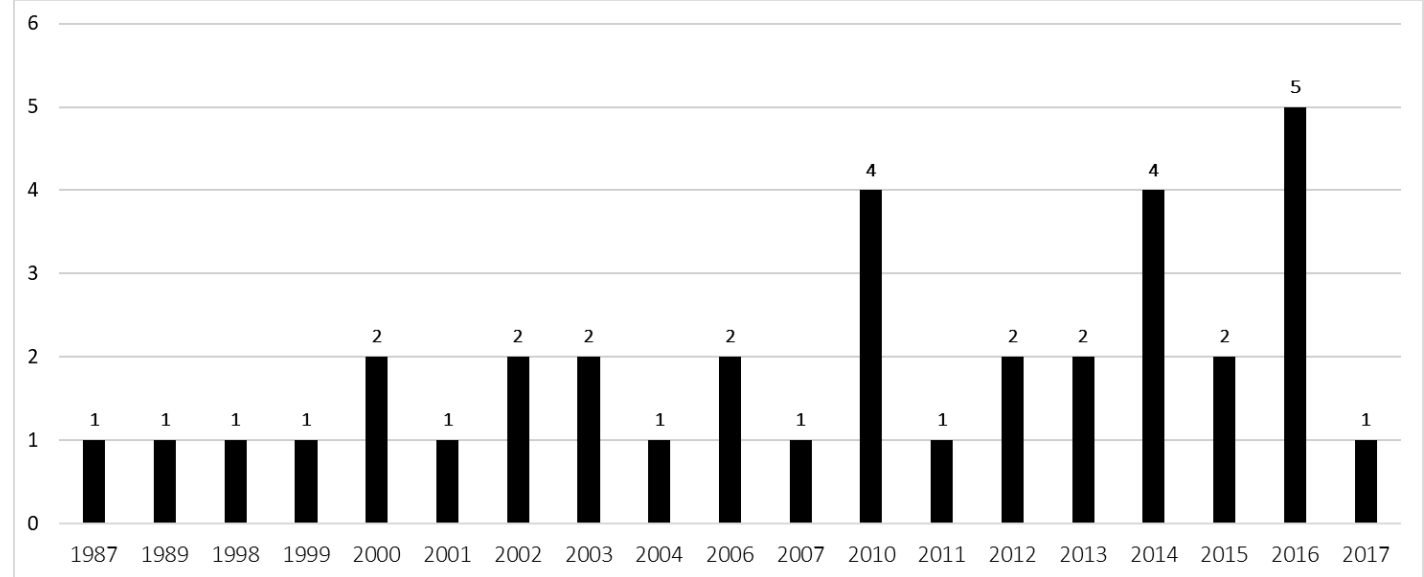


Table 3 - Sources of publication

\begin{tabular}{|c|c|c|}
\hline Source & $\begin{array}{c}\text { Number of } \\
\text { articles }\end{array}$ & Authors and year of publication \\
\hline $\begin{array}{l}\text { Construction Management and } \\
\text { Economics }\end{array}$ & 7 & $\begin{array}{l}\text { Sexton e Barrett (2003), Ling (2003), Seaden } e t \\
\text { al. (2003), Hartmann (2006), Manley e } \\
\text { McFallan (2006), Gambatese e Hallowell (2011) } \\
\text { e Murphy, Perera e Heaney (2015) }\end{array}$ \\
\hline $\begin{array}{l}\text { Journal of Construction Engineering } \\
\text { and Management }\end{array}$ & 6 & $\begin{array}{l}\text { Tatum (1987, 1989), Mitropoulos e Tatum } \\
\text { (1999), Pellicer } \text { et al. (2014), Fernando, } \\
\text { Panuwatwanich e Thorpe (2019) e Ercan (2019) }\end{array}$ \\
\hline $\begin{array}{l}\text { Journal of Management in } \\
\text { Engineering }\end{array}$ & 4 & $\begin{array}{l}\text { Ozorhon (2013), Chan, Liu e Fellows (2014), } \\
\text { Loosemore (2015) e Ozorhon, Oral e } \\
\text { Demirkesen (2016) }\end{array}$ \\
\hline Building Research and Information & 3 & Winch (1998) e Slaughter (2000) \\
\hline $\begin{array}{l}\text { Asian Journal of Technology } \\
\text { Innovation }\end{array}$ & 1 & Chang, Rasiah e Chan (2016) \\
\hline Construction Economics and Building & 1 & Davis et al. (2016) \\
\hline Construction Innovation & 1 & Blayse e Manley (2004) \\
\hline Engineering Management Journal & 1 & Pellicer et al. (2012) \\
\hline $\begin{array}{l}\text { Engineering, Construction and } \\
\text { Architectural Management }\end{array}$ & 1 & Pan (2010) \\
\hline Industrial Marketing Management & 1 & Bygballe e Ingemansson (2014) \\
\hline Journal of Cleaner Production & 1 & Matinaro e Liu (2017) \\
\hline $\begin{array}{l}\text { Journal of Professional Issues in } \\
\text { Engineering Education and Practice }\end{array}$ & 1 & Yepes et al. (2016) \\
\hline Procedia Engineering & 1 & Serpell e Alvarez (2014) \\
\hline $\begin{array}{l}\text { Proceedings of Institution of Civil } \\
\text { Engineers: Management, } \\
\text { Procurement and Law }\end{array}$ & 1 & Shaw, Bouchlaghem e Demian (2010) \\
\hline R\&D Management & 1 & Hauschildt e Kirchmann (2001) \\
\hline Research Policy & 1 & Gann e Salter (2000) \\
\hline $\begin{array}{l}\text { Revista Gestión de las Personas y } \\
\text { Tecnología }\end{array}$ & 1 & Calderón (2015) \\
\hline Revista Ingeniería de Construcción & 1 & Correa, Yepes e Pellicer (2007) \\
\hline Total Quality Management & 1 & Bossink (2002) \\
\hline $\begin{array}{l}\text { The Engineering Project Organization } \\
\text { Journal }\end{array}$ & 1 & Toole, Hallowell e Chinowsky (2013) \\
\hline ARCOM Conference & 1 & Gkiourka, Tutesigensi e Moodley (2010) \\
\hline $\begin{array}{l}\text { International Congress on Project } \\
\text { Management and Engineering }\end{array}$ & 1 & Pellicer et al. (2015) \\
\hline
\end{tabular}

Figure 5 - Frequency of the publications per country



392 Duarte, C. M. de M.; Picchi, F. A. 
In addition to the boundaries of research, other contextual information that has been extracted concerns the type of innovation considered in the studies selected. Some authors have limited their research to an investigation of the technological innovation process, that is, product and process innovations. However, about $95 \%$ of the studies address innovation in a general way, considering not only technological but also organizational and marketing (ORGANIZATION..., 2005). Given the above, it is clear that the contribution of this SLR is aimed at researchers and practitioners related to the various sectors of the construction industry that seek to understand how to enhance the innovation process within the construction firms.

\section{Results and discussion}

The 38 studies selected were thoroughly examined in a search for elements that enable systemic innovation in construction firms. After arriving at 15 distinguishable enablers, they were classified into five aspects of innovation management: strategic, organizational, human, processual, and financial (Figure 6). It is important to note that, during this process, some of them were merged or revised to achieve the final classification. It turns out that some enablers permeate two or more aspects of innovation and incorporating them in just one involved a certain degree of subjectivism.

Figure 7 illustrates the number of articles referring to each innovation enabler. Knowledge Management (Processual), as an enabler of systemic innovation, is mentioned in 29 of the 38 selected papers. Other three enablers worth mentioning since all are covered in more than half of the analyzed articles: Upper Management Support (Organizational) - 22, External Collaboration (Strategic) - 21, and Innovation Culture (Organizational) - 20. No enabler in Human and Financial aspects have more than 16 references, possibly indicating potential focus for future studies.

Each of the 15 different enablers are discussed in the sequence, mainly considering the concepts and approaches used in the articles selected in the SLR. Also, some practices, routines, methods, and tools that can be adopted to increase construction firms' innovation activity are presented and synthesized at the end of the section.

Figure 6 - Aspects of innovation management and enablers of innovation

\begin{tabular}{|c|c|c|}
\hline ASPECTS & & ENABLERS \\
\hline \multirow{3}{*}{$\begin{array}{l}\text { STRATEGIC ASPECT } \\
\text { (STRATEGY) }\end{array}$} & 1 & Innovation Strategy \\
\hline & 2 & External Collaboration (Open Innovation) \\
\hline & 3 & Customer Centricity \\
\hline \multirow{4}{*}{$\begin{array}{l}\text { ORGANIZATIONAL ASPECT } \\
\text { (ORGANIZATION) }\end{array}$} & 4 & Upper Management Support (Leadership) \\
\hline & 5 & Innovation Culture \\
\hline & 6 & Incentive System \\
\hline & 7 & Organizational Unit for Innovation \\
\hline \multirow{3}{*}{$\begin{array}{c}\text { HUMAN ASPECT } \\
\text { (HUMAN RESOURCES) }\end{array}$} & 8 & Innovation Champion (Key Individuals) \\
\hline & 9 & Training for Innovation \\
\hline & 10 & Multidisciplinary Teams \\
\hline \multirow{4}{*}{$\begin{array}{l}\text { PROCESSUAL ASPECT } \\
\text { (PROCESS) }\end{array}$} & 11 & Technological Watch \\
\hline & 12 & Idea Management \\
\hline & 13 & Knowledge Management \\
\hline & 14 & Integration of Innovation and Quality Management \\
\hline $\begin{array}{c}\text { FINANCIAL ASPECT } \\
\text { (FINANCIAL RESOURCES) }\end{array}$ & 15 & Budget for Innovation \\
\hline
\end{tabular}


Figure 7 - Number of articles referring to each innovation enabler

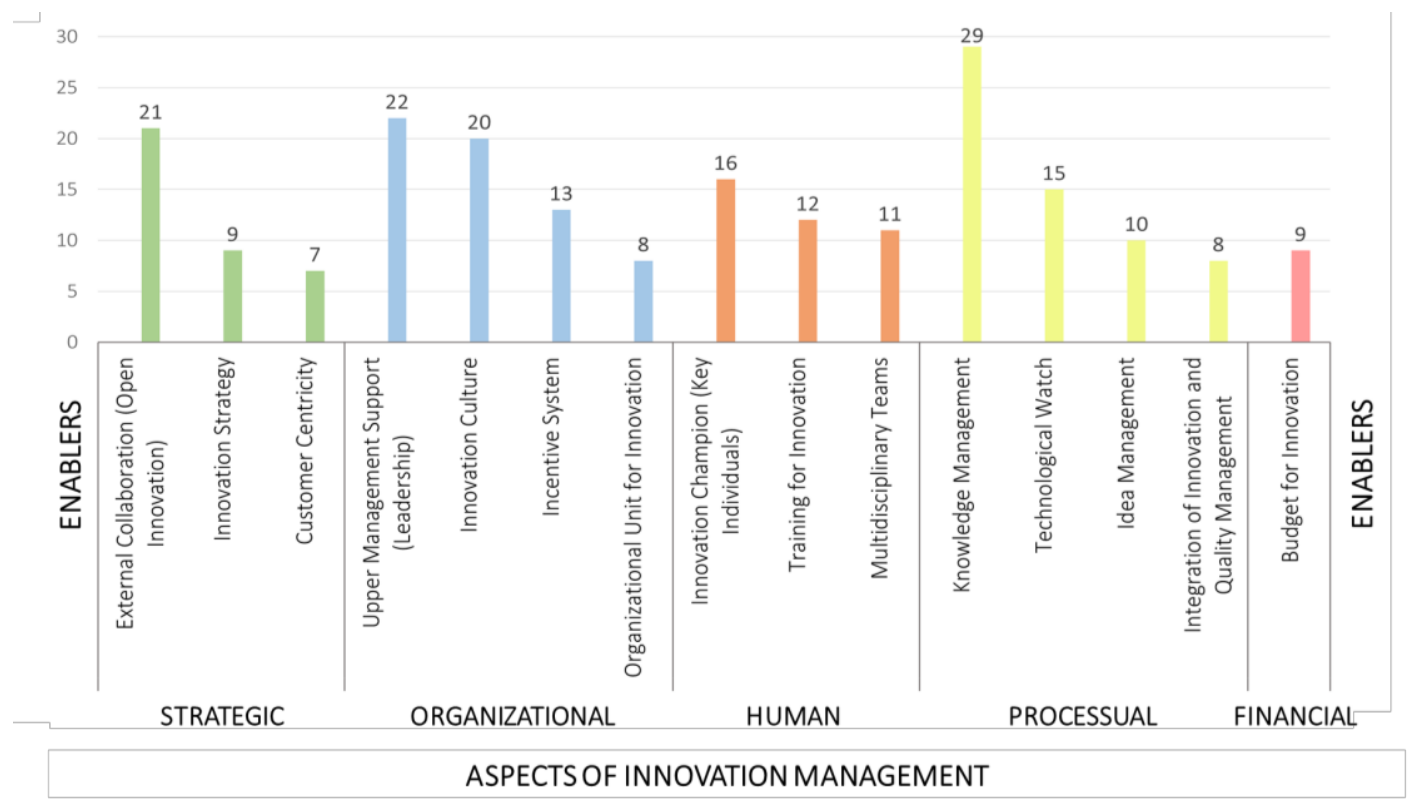

\section{Strategic aspect (strategy)}

\section{Innovation strategy}

A clear and well-defined innovation strategy is essential for continuous innovation. It permeates all aspects of innovation management and influences, directly and indirectly, all other enablers identified in this review. Based on it, the course of innovation will be determined, which means the organizational plans aimed at the development of new products, processes, services, etc. (TATUM, 1987). Loosemore (2015, p. 5) emphasizes that the innovation strategy is "[...] key to giving people permission to innovate and communicating that innovation matters $[\ldots] "$.

Besides motivating the generation of new ideas by employees, the innovation strategy must be able to provide the company with the necessary resources, support the R\&D management model and, in particular, provide the information, policies, and objectives that guide the innovative process within the organization (CORREA; YEPES; PELLICER, 2007; LOOSEMORE, 2015). To design an innovation strategy, one must consider the business environment and the organizational capabilities (PELLICER et al., 2015). As few firms in the construction industry have resources or incentives to develop innovations, it is essential to define a strategy that prioritizes the adoption of new technologies developed elsewhere (BLAYSE; MANLEY, 2004).

A key point is to align innovation with the organization's business strategy. Not only to set the stage for competitiveness sustained by innovation but also to develop a new way of doing things - more productive, more agile, and more integrative (LAFLEY; CHARAN, 2008). It is also important to define what types of innovation will allow the company to create and capture value, and what resources each should receive. To that end, construction firms must broaden their vision of innovation and stop seeing it only in terms of new products or new processes (STEWART; FENN, 2006).

\section{External collaboration (open innovation)}

Collaboration is seen as one of the strongest enablers of construction innovation, since only a small portion of the innovations occur in isolated environments (OZORHON; ORAL; DEMIRKESEN, 2016). Successful innovation requires active cooperation, coordination, and integration among other industry players, such as suppliers, designers, startups, clients, and even competitors (TATUM, 1989; LING, 2003; PELLICER et al., 2014). Open innovation practices may complement internal technology capabilities such as applying new technologies for problem-solving, the integration of external technological resources with company resources, or the motivation of talented expert employees (ERCAN, 2019). It can be an option for a company to start an innovative internal process. 
Suppliers and designers are essential sources of collaboration for the development of product innovations. Although not a common practice in the construction industry, collaboration with research centers and universities has a positive and significant impact on innovation activity (SERPELL; ALVAREZ, 2014). These knowledge-oriented institutions provided an overview of the problem, as well as scientific guidance that construction firms might lack (PELLICER et al., 2012). In turn, programs connecting construction firms with startups have been increasingly common, creating a massive potential for innovation in various shapes and forms.

Regardless of the type of partnership, open innovation must be adopted strategically, with clearly defined objectives. For open innovation to deliver the expected results, it is important to establish criteria to identify, evaluate and select partners (INTERNATIONAL..., 2019). Trust is an essential factor when adopting open innovation (CHANG; RASIAH; CHAN, 2016). Innovation partnership is usually formalized through a written agreement, which may contain confidentiality and intellectual property transfer clauses depending on the type of innovation developed (PELLICER et al., 2015).

\section{Customer centricity}

Even though there are other sources of innovation, client requirements are among the most important reasons to innovate (PELLICER et al., 2014). Throughout the innovation process, the organization must focus on customer needs (TOOLE; HALLOWELL; CHINOWSKY, 2013). Customer satisfaction measurement contributes to the initiation of innovation processes (BOSSINK, 2002), and innovative solutions must be analyzed concerning the added value they offer to the client (HARTMANN, 2006). However, few construction firms have a structured process to identify, understand, and prioritize customer needs for innovation, a widespread practice in customercentric organizations.

In a customer centricity logic, organizations centralize all strategic planning in the customer experience. From the perspective of innovation, every new product or service is developed to provide a satisfactory experience for the customer (OZAKI, 2003; FRANKENBERGER; WEIBLEN; GASSMANN, 2013). These organizations have the ability to detect requirements from demanding clients, which is essential for the innovation process (PELLICER et al., 2014). Some of them have resorted to the design thinking approach to develop innovative solutions based on customer journey mapping, which is the process the customer goes through, across all stages and touchpoints with an organization, comprising the customer experience (LEMON; VERHOEF, 2016).

It is also worth mentioning that in a customer-centric culture of innovation, all sectors of the organization are committed to obtaining and collecting innovative insights, focusing on users and customers.

\section{Organizational aspect (organization)}

\section{Upper management support (leadership)}

Leadership is also indicated as one of the main enablers of innovation, both at a firm-level and a projectlevel perspective. Leaders can be considered agents of change, serving an important role in developing and sustaining an environment conducive to innovation (GAMBATESE; HALLOWELL, 2011). They should "[...] build a culture of tolerance, transparency, trust, and openness that enables people to put forward ideas in confidence and take calculated risks without fear of blame or failure [...]" (LOOSEMORE, 2015, p. 4). Teams that receive upper management support tend to act proactively in seeking opportunities to innovate (SHAW; BOUCHLAGHEM; DEMIAN, 2010). A leader's role is not only to encourage innovation but also to work diligently to remove the obstacles that can prevent it.

Values-driven leaders lead from a deep sense of purpose and a demonstrated commitment to, what is extremely important for the consolidation of a culture of innovation (MATINARO; LIU, 2017). Willingness, ability to listen, attitude, open-mindedness, vision, and commitment for improvement, are some characteristics innovation leaders have in common (OZORHON, 2013; TOOLE; HALLOWELL; CHINOWSKY, 2013).

Chan, Liu and Fellows (2014) emphasize that different leadership types have different effects on innovation. Innovative companies designate different leadership profiles for the various stages of the innovation process. In early stages, such as the generation and selection of ideas, the focus of leadership should be on stimulating creativity and ensuring a less critical environment. In implementing innovation, the leader must focus on coordinating and providing operational support to the team involved (KING; ANDERSON, 2002). 


\section{Innovation culture}

For innovation to thrive, there needs to be a conducive environment within the organization (FERNANDO; PANUWATWANICH; THORPE, 2019). Innovation culture is a concept that connects an organization's intrinsic characteristics to the innovation process, comprising an essential enabler of systemic innovation.

Innovation culture is strictly related to innovation strategy and involves core beliefs, behaviors, and practices, such as: encouraging and supporting employees to question the status quo (HARTMANN, 2006); multidisciplinary teams (PELLICER et al., 2014; MATINARO; LIU, 2017); organizational flexibility (TATUM, 1987; LOOSEMORE, 2015); training for innovation (SERPELL; ALVAREZ, 2014); the incentive to creativity (CORREA; YEPES; PELLICER, 2007); tolerance of risk, failure, and mistakes when promoting innovation (OZORHON; ORAL; DEMIRKESEN, 2016); among others. It is important to note that many of these practices are mutual-correlated. For example, by having a flexible organizational structure, a company allow innovators to bypass barriers and hierarchies that often undermine creativity.

Construction firms that intend to innovate in a systemic way, need to create an environment in which people feel comfortable to innovate and feel a duty to do so without consciously (LOOSEMORE, 2015). A first step to be taken is to sensitize employees to innovation and its opportunities, motivate and inspire them to engage in innovation alongside their day-to-day business. It requires the leadership's direct involvement, resource allocation, and training. Innovation culture must permeate the entire organization. It is a process that takes some time to consolidate and generate good results, especially in a traditionally conservative industry, such as construction.

\section{Incentive system}

An incentive system is an example of a specific measure to foster innovation. It is directly linked with innovation culture, which can be reinforced with rewards schemes to nurture an innovation mindset (LOOSEMORE, 2015). Incentivisation encourages team members to work harder. It also exposes the organization's priorities and shows its commitment (TOOLE; HALLOWELL; CHINOWSKY, 2013). Without proper compensation for the ideas they championed, individuals may be less inclined to pursue new valuable projects. Apart from the relative success of innovation, the personnel involved in the implementation stages should be rewarded (FERNANDO; PANUWATWANICH; THORPE, 2019). In this case, it is not the outcome being rewarding, but the innovative behavior and the innovation process.

Financial compensation is not the only way to encourage an innovative attitude. Some of the rewards are intrinsic to the innovation process itself, like providing personal pride and challenges to the people involved. Besides, when it comes to incremental innovations, the organization can give explicit rewards, such as formal recognition within the company or a straightforward expansion of the job description to include innovation or other related activities (SLAUGHTER, 2000). In the case of construction firms aiming to develop radical innovations, it is recommended to structure an intellectual property process that strengthens employees' trust to contribute with good ideas.

\section{Organizational unit for innovation}

As previously stated, innovation should be embraced by the whole organization. Leadership is not always enough to spread the company's innovation strategy and innovation culture. Therefore, an organizational unit for innovation can be a catalyst for innovation and act as the change agent.

In some construction companies, this role is played by the R\&D departments (PAN, 2010; OZORHON; ORAL; DEMIRKESEN, 2016). In smaller ones, this unit can start with just one person, until the innovation process gains strength and requires a larger team (PELLICER et al., 2012). Another alternative is creating innovation committees, that is, a discussion forum responsible for directing the organization's innovative activities. It must have representatives from different areas of the business, and it is strictly recommended that it includes leaders to gain agility.

Likewise, the role of internal service units, such as engineering departments, should be strengthened. These units may assist project teams in investigating the feasibility of innovative ideas, elaborating ideas until the added value in contrast to conventional solutions is recognisable, and solving further problems during implementation (HARTMANN, 2006). Another way is to find individuals with an innovative profile to act as gatekeepers, seeking innovation opportunities (TATUM, 1987; SLAUGHTER, 2000). 


\section{Human aspect (human resourses) \\ Innovation champion (key individuals)}

Champions are individuals who give active and intensive support to the innovation process (HAUSCHILDT; KIRCHMANN, 2001). They are key individuals who commit with enthusiasm to the new ideas and take risks to make innovations happen. A champion has some characteristics of an independent entrepreneur, but he operates within an existing business. A champion's attributes include possession, at the very least, of power and technical competence to overcome the uncertainty of construction innovation (BLAYSE; MANLEY, 2004).

Innovative companies usually have more than one innovation champion. They can emerge from different areas of the business. The champion's role involves three levels: the technical champion (lead technological innovations); the business champion (lead organizational and business model innovations); and the executive champion, who sponsors the idea at the highest level (TATUM, 1987). Some construction firms start their innovation processes by hiring people with an innovative mindset from more intense technology sectors. They can give a new boost to the organizational environment and can help to break construction's inherent conservatism.

\section{Training for innovation}

Training is an essential element to enhance construction innovation. Managers should develop their employees by giving them the skills and knowledge to innovate (LOOSEMORE, 2015). Project-based industries such as construction create special needs for technical capabilities in innovation (TATUM, 1987). Such capabilities comprise the technologies and technical skills that empower the firm to adapt quickly to opportunities (MANLEY; MCFALLAN, 2006). Innovative companies develop a training policy that embraces technical, managerial, and creative skills. Furthermore, it invests in training aimed at better comprehension of the organization's innovation practices.

Several authors emphasize the importance of on-site training and learning to change existing skills and competencies of personnel implementing innovation (OZORHON; ORAL; DEMIRKESEN, 2016; SLAUGHTER, 2000; ERCAN, 2019). It is also important to highlight that different innovations types require different levels of training.

It is interesting to note that innovative construction firms not only establish a training policy focused on innovation but also adopt innovative practices in compulsory training programs, such as those related to health and safety at work (AHN et al., 2020). Gamification, Blended Learning, and Interactive Guidance are examples of innovative techniques already adopted in construction.

\section{Multidisciplinary teams}

A multidisciplinary team plays an essential role in innovation processes. This practice is strongly related to the organizational aspect of innovation management, especially to innovation culture, as highlighted before. Organizations that want to foster innovation should provide an environment where people from different backgrounds and experiences can interact and build on others' knowledge (FERNANDO; PANUWATWANICH; THORPE, 2019). When structuring a multidisciplinary team, it must be noted that construction engineering does not conveniently fit within the traditional engineering disciplines. It is necessary to incorporate professionals from related technical subjects, such as mechanical and electrical (TATUM, 1987).

Communication can be challenging in a multidisciplinary team, so it is crucial to establish agreed systems and protocols for interaction between members. Pellicer et al. (2014) highlight the importance of multidisciplinary teams' proper management to ensure the necessary conditions for innovation.

\section{Processual aspect (process)}

\section{Technological watch}

"Technology watch is a systematic and organized effort to observe, collect, analyze, disseminate, and retrieve accurate information relevant to the business environment [...]" (YEPES et al., 2016, p. 4). It is not yet a widespread practice in the construction industry. On the contrary, only large companies have established routines for the systematic search for new technologies (DAVIDSON, 2001). 
Innovative companies establish routines and processes to monitor the external environment in search of new solutions. They encourage employees to look outside of their day to day activities for innovation opportunities, overcoming the 'not-invented-here' syndrome (TOOLE; HALLOWELL; CHINOWSKY, 2013). Slaughter (2000) recommends designating a "gatekeeper" within the company to aware of potential solutions that might apply to the problem at hand. Technology watch is bound to the innovation strategy, so managers must monitor the core technologies for the company strategically.

\section{Idea management}

Idea management is one of the essential elements to enable systemic innovation. It is a process of generating, organizing, selecting, and developing valuable ideas that would otherwise not have emerged through conventional means. The opportunities to innovate are abundant, and ideas can come from different internal and external sources (BOEDDRICH, 2004). Innovative construction firms establish a formal process to collect and organize ideas, which can arise spontaneously or through methods and techniques to stimulate the generation of ideas. They often resort to software especially designed to host ideas in an orderly manner (CALDERÓN, 2015).

Many organizations collect internal ideas through suggestion programs or systems (BARBIERI; ÁLVARES; CAJAZEIRA, 2009). Others have been using platforms to capture external ideas based on the collaborative process called crowdsourcing (HOWE, 2006). In companies with an innovation culture already established, idea management is a practice incorporated in the innovation management system (PELLICER et al., 2015).

\section{Knowledge management}

Knowledge management and innovation management are intrinsically linked. Within the context of the construction industry, knowledge management in the organization enables transfer findings and practices from projects to other projects (PELLICER et al., 2014). For problem-solving to become innovation, the new solutions developed for the particular problem faced on the project must be learned, codified, and applied to future projects (WINCH, 1998). It is necessary to ensure that a flow of information and knowledge about current and past projects is adequately stored (GANN; SALTER, 2000). Managers should provide the mechanisms and tools that foster knowledge sharing within a group to facilitate innovation (OZORHON; ORAL; DEMIRKESEN, 2016).

The success of knowledge management in the innovation process depends on the involvement of the entire organization. It is essential that each employee understands the importance of the discipline and is committed to sharing information and knowledge. Chang, Rasiah e Chan (2016, p. 285) emphasize that "[...] the knowledge sharing culture is strengthened if it is driven by top management and senior staff and a group culture.". It is worth mentioning that the knowledge management driver refers both to internal and external knowledge (SERPELL; ALVAREZ, 2014).

Knowledge management in construction is still a challenging task. But some firms have been creating Community of Practices (CoPs) to generate and deliver value to the organization and contribute towards the collective organizational intelligence. CoPs are recognized as being resourceful sources of innovations and professional best practices in the construction industry (RUIKAR; KOSKELA; SEXTON, 2009).

\section{Integration of innovation and quality management}

Quality management is a well-established practice in the construction industry. Quality management pillars, such as process approach, customer focus, relationship management and evidence-based decision making, can anchor the systemic innovation processes. According to Bossink (2002), tools in strategic quality management can be useful in creating the organizational conditions in which innovations can be developed, supervising and initiating innovation processes, producing innovation content, and implementing innovations in the organization's primary processes.

Research by Pellicer et al. $(2012,2014,2015)$ presents the systematization of innovation management through the Spanish standard UNE 166002, which is based on the ISO 9001 standard for quality management. The authors detail the implementation of the innovation management system in a mediumsized construction company and reinforce that the two integrated practices enhance innovation activity in construction firms.

The ISO 56002 (INTERNATIONAL..., 2019) (Innovation Management System) also has a structure integrated with the ISO 9001, which can serve as a basis for a construction firm that intends to manage its 
innovation processes (INTERNATIONAL..., 2019). It can start by developing an innovation management process within the quality management system itself, considering its strategic innovation priorities.

\section{Financial aspect (financial resources)}

\section{Budget for innovation}

The last enabler of innovation in construction regards the financial resources for innovation. It is undoubtedly an essential factor in enabling continuous innovation in any organization. Innovation requires organizational support. An integral and foundational component of this support is allocating budget resources to innovation efforts (TOOLE; HALLOWELL; CHINOWSKY, 2013). Innovative firms put corporate-level resources in place to fund innovation (FERNANDO; PANUWATWANICH; THORPE, 2019).

The innovation strategy should target the resources needed for the implementation of innovations and maintenance of the innovation system. In the case of scarcity of resources, the organization can raise funds from external sources (open innovation, agency to foster innovation, etc.).

\section{Synthesis of the results}

Figure 8 summarizes all practices, routines, methods, or tools identified throughout this study. With it, the authors intend to present, albeit briefly, different ways a construction firm can take to systematize its innovation processes.

\section{Conclusions}

Through a Systematic Literature Review (SLR), this study sought to identify, compile, classify, and summarize the key elements to enable systemic innovation in construction firms. From the analytical reading of 38 selected articles, 15 different enablers of innovation in construction firms were identified and then classified into five categories, referred to as "Aspects of Innovation Management": strategic, organizational, human, processual, and financial.

Concerning the Strategic Aspect, three enablers were identified: Innovation Strategy, External Collaboration (Open Innovation), and Customer Centricity. The innovation strategy guides the company's innovative efforts and, therefore, directly and indirectly influences all other aspects and enablers identified in the study. A clear and well-defined innovation strategy, aligned with the organization's business strategy, is crucial for companies to carry out innovation activities efficiently and purposefully. This corroborates the initial hypothesis that innovation needs to be seen as a strategic issue to become something the firm systematically does. Collaboration emerges as one of the main enablers of construction innovation. By their innovation processes, companies can complement internal technology capabilities, reduce costs, share risks, and generate ideas and knowledge base. A customer-centric company can anticipate the demand for new products and services, making innovation somewhat dynamic. To do so, construction firms need to structure a process to identify, understand, and prioritize customer needs for innovation.

The Organizational Aspect includes four enablers: Upper Management Support (Leadership), Innovation Culture, Incentive System, and Organizational Unit for Innovation. Most of the reviewed papers highlight leadership as fundamental for promoting systematic innovation. Leaders are agents of change and are responsible for consolidating the culture of innovation in the company. In turn, the culture of innovation permeates all aspects of innovation management. It influences the other enablers from the Organizational Aspect and, mainly, from the Human Aspect. Implementing a culture of innovation is challenging, requiring structural changes in the organization, flexibility, incentive to creativity, and risk tolerance. An incentive system is also related to both people and financial resources. Thus, it was classified as an Organization Aspect precisely because of its connection with the innovation culture. An organizational unit for innovation was one of the least mentioned enablers in the literature, but it plays an important role: being a catalyst for innovation. A structured innovation unit supports all elements of the procedural aspect, facilitating the development of practices, routines, processes, and tools. 
Figure 8 - Aspects, enablers, and its related practices, routines, methods, or tools

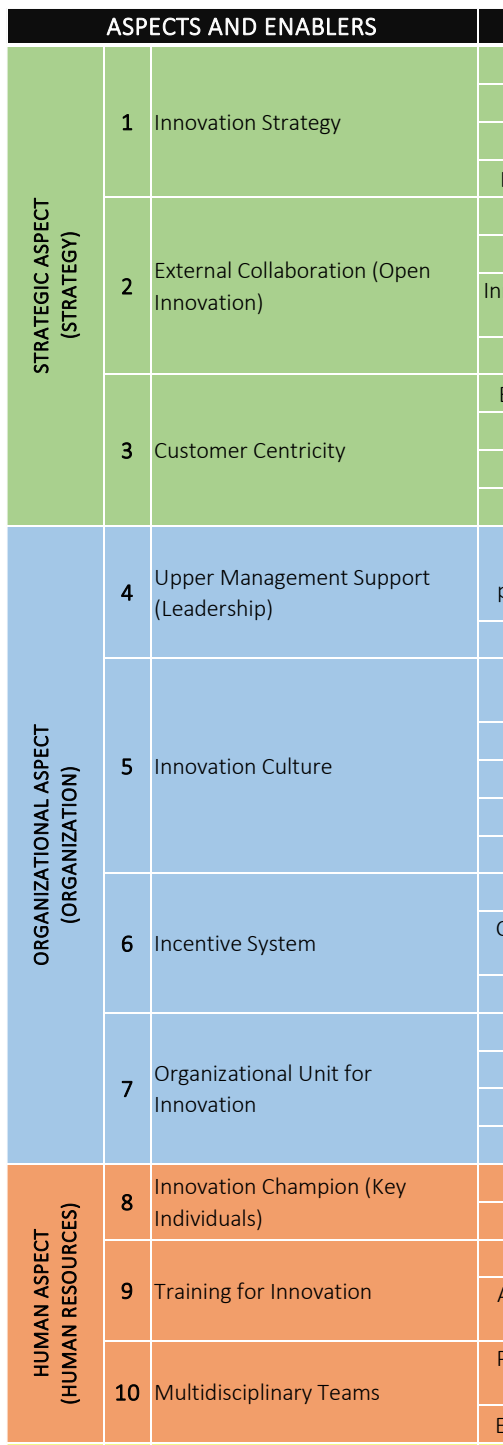

11 Technological Watch RELATED PRACTICES, ROUTINES, METHODS OR TOOLS

Innovation aligned with the organization's business strategy. Clear innovation strategy, considering the business environment and organizational capabilities. Innovation strategy is disseminated to reach all areas of the organization.

Broaden vision of innovation (product, service, process, organizational, marketing, business model). Open innovation adopted strategically, with clearly defined objectives. Establish criteria to identify, evaluate and select innovation partners.

nnovation partnership formalized through written agreement (resort to confidentiality and intellectual property transfer clauses when needed).

Resort to confidentiality agreements and intellectual property transfer agreements.

Establish a structured process to identify, understand, and prioritize customer needs for innovation. Use customer satisfaction measurements as input to innovation processes.

Innovative solutions must be analysed concerning the added value they offer to the client. Customer Journey Mapping - Design Thinking Approach.

Leaders focus on building a culture of tolerance, transparency, trust, and openness (which enables people to put forward ideas in confidence and take calculated risks without fear of blame or failure)

Designate different leadership profiles for the differents stages of the innovation process.

Sensitize employees to innovation and its opportunities, motivate and inspire them to engage in innovation alongside their day-to-day activities. Organizational flexibility.

Establish a risk tolerance policy. Incentive to creativity. Innovation culture permeates the entire organization. Design an incentive system that encourage innovative attitude.

Consider different incentives for different innovation outcomes (e.g., financial compensation, formal recognition within the company, or an explicit expansion of the job description). Intellectual property process that strengthens employees' trust to contribute with good ideas. Create an organizational unit for innovation (catalyst for innovation and act as the change agent).

Create innovation committees (with representatives from different areas of the business). Strength the role of internal service units, such as engineering departments. Find individuals with an innovative profile to act as gatekeepers, seeking innovation opportunities. Seek for innovation champions in the different areas of the bussiness. Hire people with an innovative mindset frommore intense technology sectors. Establish a training policy that embraces technical, managerial, and creative skills. Adopt innovative practices in any regular training program (e.g., Gamification, Blended Learning, and Interactive Guidance)

Provide an environment where people from different backgrounds and experiences can interact and build on others' knowledge.

Establish agreed systems and protocols for communication and interaction between team members. Encourage employees to look outside of their day to day activities for innovation opportunities.

Establish routines for the systematic search for new technologies.

Designate a "gatekeeper" within the company to aware of potential solutions that might apply to the problem at hand.

Establish a formal process for the management of ideas.

Resort to software specially designed to host ideas in an orderly manner.

Create suggestion programs or systems to collect internal ideas.

Use platforms to capture external ideas (crowdsourcing).

Establish a knowledge management policy that involves the entire organization.

13 Knowledge Management

Provide mechanisms and tools to foster knowledge sharing from projects to other projects. Create Community of Practices (CoPs).

Use quality management tools to create organizational conditions for systemic innovation (e.g., customer satisfaction assessment and performance measurement).

14 Integration of Innovation and

14 Quality Management

Develop an innovation management process within the quality management system (according to strategic innovation priorities)

Implement the guidelines of an Innovation Management Standards (e.g., ISO 56002: 2019)

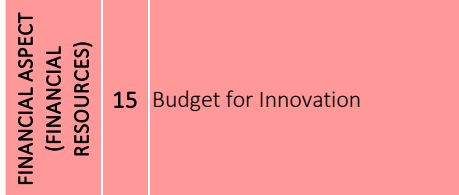

The resources needed for implementing innovations and maintaining the innovation system are provided for in the innovation strategy.

Raise funds from external sources (e.g., open innovation and agency to foster innovation). 
The third aspect concerns human resources and considers the role of Innovation Champions to lead innovation, the importance of Training for Innovation to enhance individuals' creative potential, and the benefits of forming Multidisciplinary Teams. Innovation Champions can inspire and help to consolidate the innovation culture throughout the company. References emphasize that innovative companies develop a training policy that embraces technical, managerial, and creative skills. Furthermore, it invests in training aimed at better comprehension of the organization's innovation practices. Organizations that want to foster innovation should provide an environment where people from different backgrounds and experiences can interact and build on others' knowledge. Multidisciplinary teams play an essential role in innovation outcomes, and the practice is strongly related to the Organizational Aspect of innovation management, especially to innovation culture.

The five enablers that make up the Processual Aspect are practices associated with innovation management and considered essential for continuous innovation. Knowledge Management was the most mentioned enabler in the revised literature, and its success depends on the involvement of the entire organization in the innovation process. The other enablers of the Processual aspect are: Technological watch, Idea management, and Integration of Innovation and Quality Management. The first two are practices that can be established and systematized based on the last one.

Finally, in the Financial Aspect, the Budget for Innovation is the only enabler identified. It also has a strong correlation with the innovation strategy and a significant influence on the innovation culture since innovative activities' success depends on organizational support.

The research findings contribute to a more comprehensive understanding of the key elements that enable systemic innovation in construction, considering a firm-level perspective. Given the study's exploratory nature, there was no intention of an exhaustive deepening in each of the enablers, nor did it intend to investigate the degree of influence of one over the other, which opens up several paths for the development of future research. Besides the enablers, it was also possible to identify practices, routines, methods, or tools that can be serving as a starting point for companies that intend to structure their innovation processes, making it a discipline, not an isolated event.

One of the limitations of this study concerns the research topic itself. Innovation is a multidisciplinary and comprehensive theme. There is no homogeneity in terminology and concepts, which can lead to research bias. Therefore, even though the SLR has been conducted with methodological rigor, many studies may have been left out of the search. A new search with different keywords from different databases needs to be completed to extend the findings. It may be helpful to perform the same type of analysis with different keywords. This could provide a different perspective from which to understand construction innovation management.

\section{References}

AHN, S. et al. Improving effectiveness of safety training at construction worksite using 3D BIM simulation. Advances in Civil Engineering, v. 2020, p. 1-12, feb. 2020.

BARBIERI, J. C.; ÁLVARES, A. C. T.; CAJAZEIRA, J. E. R. Gestão de ideias para inovação contínua. Porto Alegre: Bookman, 2009.

BARRETT, P.; SEXTON, M.; LEE, A. Innovation in small construction firms. London: Taylor \& Francis, 2008.

BLAYSE, A. M.; MANLEY, K. Key influences on construction innovation. Construction Innovation, v. 4, n. 3, p. 143-154, set. 2004.

BOEDDRICH, H.-J. Ideas in the workplace: a new approach towards organizing the fuzzy front end of the innovation process. Creativity and Innovation Management, v. 13, n. 4, p. 274-285, dec. 2004.

BOSSINK, B. A. G. Managing drivers of innovation in construction networks. Journal of Construction Engineering and Management, v. 130, n. 3, p. 337-345, jun. 2004.

BOSSINK, B. A. G. The strategic function of quality in the management of innovation. Total Quality Management, v. 13, n. 2, p. 195-205, mar. 2002.

BYGBALLE, L. E.; INGEMANSSON, M. The logic of innovation in construction. Industrial Marketing Management, v. 43, n. 3, p. 512-524, apr. 2014. 
CALDERÓN, G. G. El rol de recursos humanos en la gestión de la innovación en empresas constructoras. Gestión de Las Personas y Tecnología, Santiago, v. 8, n. 24, p. 17-29, oct. 2015.

CHAN, I. Y. S.; LIU, A. M. M.; FELLOWS, R. Role of leadership in fostering an innovation climate in construction firms. Journal of Management in Engineering, v. 30, n. 6, p. 06014003, nov. 2014.

CHANG, Y. F.; RASIAH, R.; CHAN, W. M. Understanding innovations in Malaysia's construction industry: a study of four large national firms. Asian Journal of Technology Innovation, v. 24, n. 3, p. 275 292, sept. 2016.

CORREA, C. L.; YEPES, V.; PELLICER, E. Factores determinantes y propuestas para la gestión de la innovación en las empresas constructoras. Revista Ingeniería de Construcción, Santiago, v. 22, n. 1, p. 05 14, apr. 2007.

CROSSAN, M. M.; APAYDIN, M. A multi-dimensional framework of organizational innovation: a systematic review of the literature. Journal of Management Studies, v. 47, n. 6, p. 1154-1191, sept. 2009.

DAVIDSON, C. H. Technology watch in the construction sector: why and how? Building Research \& Information, v. 29, n. 3, p. 233-241, may 2001.

DAVIS, P. et al. Assessing construction innovation: theoretical and practical perspectives. Construction Economics and Building, v. 16, n. 3, p. 104-115, sept. 2016.

DURIAU, V. J.; REGER, R. K.; PFARRER, M. D. A content analysis of the content analysis literature in organization studies: research themes, data sources, and methodological refinements. Organizational Research Methods, v. 10, n. 1, p. 5-34, jan. 2007.

ERCAN, T. New three-part model of innovation activity in construction companies. Journal of Construction Engineering and Management, v. 145, n. 5, p. 04019022 , may 2019.

FERNANDO, S.; PANUWATWANICH, K.; THORPE, D. Analyzing client-led innovation enablers in Australian construction projects. International Journal of Managing Projects in Business, v. 13, n. 2, p. 388-408, 22 jun. 2019.

FRANKENBERGER, K.; WEIBLEN, T.; GASSMANN, O. Network configuration, customer centricity, and performance of open business models: a solution provider perspective. Industrial Marketing Management, v. 42, n. 5, p. 671-682, jul. 2013.

GAMBATESE, J. A.; HALLOWELL, M. Enabling and measuring innovation in the construction industry. Construction Management and Economics, v. 29, n. 6, p. 553-567, jun. 2011.

GANN, D. M; SALTER, A. J. Innovation in project-based, service-enhanced firms: the construction of complex products and systems. Research Policy, v. 29, n. 7-8, p. 955-972, aug. 2000.

GKIOURKA, P.; TUTESIGENSI, A.; MOODLEY, K. A holistic conceptual model for managing innovation. In: ANNUAL ARCOM CONFERENCE, 26., Leeds, 2010. Proceedings [...] Leeds: Association of Researchers in Construction Management, 2010.

GOUGH, D.; THOMAS, J. Commonality and diversity in reviews. In: GOUGH, D.; OLIVER, S.; THOMAS, J. An introduction to systematic reviews. London: Sage, 2012.

GUSENBAUER, M.; HADDAWAY, N. R. Which academic search systems are suitable for systematic reviews or meta- analyses? Evaluating retrieval qualities of Google Scholar, PubMed, and 26 other resources. Research Synthesis Methods, v. 11, n. 2, p. 181-217, 28 jan. 2020.

HARTMANN, A. The context of innovation management in construction firms. Construction Management and Economics, v. 24, n. 6, p. 567-578, jun. 2006.

HAUSCHILDT, J.; KIRCHMANN, E. Teamwork for innovation: the 'troika' of promotors. R\&d Management, v. 31, n. 1, p. 41-49, jan. 2001.

HOWE, J. The rise of crowdsourcing. 2006. Available: https:/www.wired.com/2006/06/crowds/. Access: 15 may 2020

INTERNATIONAL ORGANIZATION FOR STANDARDIZATION. ISO 56002: innovation management: innovation management system: guidance. Geneva, 2019.

KING, N.; ANDERSON, N. Managing innovation and change: a critical guide for organizations. $2^{\text {nd }}$. ed. London: Thomson, 2002. 
KITCHENHAM, B.; CHARTERS, S. Guidelines for performing systematic literature reviews in software engineering. Keele University and Durham University Joint Report, 2007. Technical Report EBSE 2007-001.

KRIPPENDORFF, K. H. Content analysis: an introduction to its methodology. $3^{\text {rd }}$. ed. London: Sage Publications, 2012.

LAFLEY, A. G.; CHARAN, R. The game-changer: how you can drive revenue and profit growth with innovation. New York: Crown Business, 2008.

LEMON, K. N.; VERHOEF, P. C. Understanding customer experience throughout the customer journey. Journal of Marketing, v. 80, n. 6, p. 69-96, nov. 2016.

LING, F. Y. Y. Managing the implementation of construction innovations. Construction Management and Economics, v. 21, n. 6, p. 635-649, sept. 2003.

LOOSEMORE, M. Construction innovation: fifth generation perspective. Journal of Management in Engineering, v. 31, n. 6, p. 04015012 , nov. 2015.

MANLEY, K.; MCFALLAN, S. Exploring the drivers of firm? Level innovation in the construction industry. Construction Management and Economics, v. 24, n. 9, p. 911-920, sept. 2006.

MATINARO, V.; LIU, Y. Towards increased innovativeness and sustainability through organizational culture: a case study of a finnish construction business. Journal of Cleaner Production, v. 142, p. 3184 3193, jan. 2017.

MIOZZO, M.; DEWICK, P. Building competitive advantage: innovation and corporate governance in European construction. Research Policy, v. 31, n. 6, p. 989-1008, aug. 2002.

MITROPOULOS, P.; TATUM, C. B. Technology adoption decisions in construction organizations. Journal of Construction Engineering and Management, v. 125, n. 5, p. 330-338, sept. 1999.

MORANDI, M. I. W. M.; CAMARGO, L. F. R. Revisão sistemática da literatura. In: DRESCH, A.; LACERDA, D. P.; ANTUNES JUNIOR, J. A. V. Design science research: método e pesquisa para avanço da ciência e da tecnologia. Porto Alegre: Bookman, 2015.

MUIANGA, E. A. D.; GRANJA, A. D.; RUIZ, J. de A. Desvios de custos e prazos em empreendimentos da construção civil: categorização e fatores de influência. Ambiente Construído, Porto Alegre, v. 15, n. 1, p. 79-97, jan./mar. 2015.

MURPHY, M. E.; PERERA, S.; HEANEY, G. Innovation management model: a tool for sustained implementation of product innovation into construction projects. Construction Management and Economics, v. 33, n. 3, p. 209-232, mar. 2015.

ORGANIZATION FOR ECONOMIC COOPERATION AND DEVELOPMENT. Oslo manual: guidelines for collecting and interpreting innovation Data. $3^{\text {rd }}$. ed. Paris: OECD, 2005.

ORSTAVIK, F.; DAINTY, A.; ABBOTT, C. (ed.). Construction innovation. Oxford: John Wiley \& Sons, 2015.

OZAKI, R. Customer- focused approaches to innovation in housebuilding. Construction Management and Economics, v. 21, n. 6, p. 557-564, sept. 2003.

OZORHON, B. Analysis of construction innovation process at project level. Journal of Management in Engineering, v. 29, n. 4, p. 455-463, oct. 2013.

OZORHON, B.; ORAL, K.; DEMIRKESEN, S. Investigating the components of innovation in construction projects. Journal of Management in Engineering, v. 32, n. 3, p. 04015052, may 2016.

PAN, W. Strategies for managing innovation in UK housebuilding. Engineering, Construction and Architectural Management, v. 17, n. 1, p. 78-88, 12 jan. 2010.

PELLICER, E. et al. Model for systematic innovation in construction companies. Journal of Construction Engineering and Management, v. 140, n. 4, p. 2-8, apr. 2014.

PELLICER, E. et al. Organizational improvement through standardization of the innovation process in construction firms. Engineering Management Journal, v. 24, n. 2, p. 40-53, jun. 2012. 
PELLICER, E. et al. The Dilemma of innovation in the construction company: a decade of lessons learned. In: INTERNATIONAL CONGRESS ON PROJECT MANAGEMENT AND ENGINEERING, 19. Granada, 2015. Proceedings [...] Valencia: Asociación de Los Profesionales de La Dirección e Ingeniería de Proyectos de España, 2015.

QUADROS, R. Aprendendo a inovar: padrões de gestão da inovação tecnológica em empresas industriais brasileiras. Campinas, 2008. Relatório Técnico.

QUINTANE, E. et al. Innovation as a knowledge- based outcome. Journal of Knowledge Management, v. 15 , n. 6 , p. $928-947,25$ oct. 2011.

RUIKAR, K.; KOSKELA, L.; SEXTON, M. Communities of practice in construction case study organisations. Construction Innovation, v. 9, n. 4, p. 434-448, 9 out. 2009.

SEADEN, G. et al. Strategic decisions and innovation in construction firms. Construction Management and Economics, v. 21, n. 6, p. 603-612, sept. 2003.

SEADEN, G.; MANSEAU, A. Public policy and construction innovation. Building Research \& Information, v. 29, n. 3, p. 182-196, may 2001.

SERPELL, A.; ALVAREZ, R. A systematic approach for evaluating innovation management in construction companies. Procedia Engineering, v. 85, p. 464-472, 2014.

SEXTON, M; BARRETT, P. Appropriate innovation in small construction firms. Construction Management and Economics, v. 21, n. 6, p. 623-633, sept. 2003.

SHAW, N.; BOUCHLAGHEM, D.; DEMIAN, P. Key influences of innovation magnitude and mode. Proceedings of the Institution of Civil Engineers - Management, Procurement and Law, v. 163, n. 4, p. 161-169, nov. 2010.

SILVA, D. O. da; BAGNO, R. B.; SALERNO, M. S. Modelos para a gestão da inovação: revisão e análise da literatura. Production, v. 24, n. 2, p. 477-490, sept. 2013.

SLAUGHTER, E. S. Implementation of construction innovations. Building Research \& Information, v. 28, n. 1, p. 2-17, jan. 2000.

SOARES, P. B. et al. Análise bibliométrica da produção científica brasileira sobre Tecnologia de Construção e Edificações na base de dados Web of Science. Ambiente Construído, Porto Alegre, v. 16, n. 1, p. 175-185, jan. 2016.

STEWART, I.; FENN, P. Strategy: the motivation for innovation. Construction Innovation, v. 6, n. 3, p. 173-185, sept. 2006.

SUPRUN, E. V.; STEWART, R. A. Construction innovation diffusion in the Russian Federation. Construction Innovation, v. 15, n. 3, p. 278-312, jul. 2015.

TATUM, C. B. Organizing to increase innovation in construction firms. Journal of Construction Engineering and Management, v. 115, n. 4, p. 602-617, dec. 1989.

TATUM, C. B. Process of Innovation in Construction Firm. Journal of Construction Engineering and Management, v. 113, n. 4, p. 648-663, dec. 1987.

TIDD, J.; BESSANT, J. Innovation management: integrating technological, market and organizational change. 5. ed. Hoboken: Wiley, 2013.

TOOLE, T. M.; HALLOWELL, M.; CHINOWSKY, P. A tool for enhancing innovation in construction organizations. Engineering Project Organization Journal, v. 3, n. 1, p. 32-50, mar. 2013.

TRANFIELD, D.; DENYER, D.; SMART, P. Towards a methodology for developing evidence-informed management knowledge by means of systematic review. British Journal of Management, v. 14, n. 3, p. 207-222, sept. 2003.

VOLBERDA, H. W.; BOSCH, F. A. J. van Den; HEIJ, C. V. Management Innovation: management as fertile ground for innovation. European Management Review, v. 10, n. 1, p. 1-15, mar. 2013.

WINCH, G. Zephyrs of creative destruction: understanding the management of innovation in construction. Building Research \& Information, v. 26, n. 5, p. 268-279, sept. 1998. 
WOHLIN, C. Guidelines for snowballing in systematic literature studies and a replication in software engineering. In: INTERNATIONAL CONFERENCE ON EVALUATION AND ASSESSMENT IN SOFTWARE ENGINEERING, 18., London, 2014. Proceedings [...] New York: Acm Digital Library, 2014.

XUE, X. et al. Innovation in Construction: a critical review and future research. International Journal of Innovation Science, v. 6, n. 2, p. 111-126, jun. 2014.

YEPES, V. et al. Creative innovation in spanish construction firms. Journal of Professional Issues in Engineering Education and Practice, v. 142, n. 1, p. 04015006, jan. 2016.

\section{Errata}

No artigo "Key elements to enable systemic innovation in construction firms", com número de DOI: $<$ http://dx.doi.org/10.1590/s1678-86212021000400575>, publicado no periódico Ambiente Construído, 21(4):385-405.

Na página 385:

Onde se lia:

"Elementos-chave para possibilitar a inicação sistêmica em empresas construtoras"

Leia-se:

"Elementos-chave para possibilitar a inovação sistêmica em empresas construtoras"

\section{Carolina Mendonça de Moraes Duarte}

Faculdade de Engenharia Civil, Arquitetura e Urbanismo | Universidade Estadual de Campinas | Instituto Federal de Alagoas | Rua Dr. Odilon Vasconcelos, 103, Jatiúca | Maceió - AL - Brasil | CEP 57035-660 | Tel.: (82) 3194-1150 | E-mail: carolina.duarte@ifal.edu.br

Flávio Augusto Picchi

Faculdade de Engenharia Civil, Arquitetura e Urbanismo | Universidade Estadual de Campinas | Lean Institute Brasil | Rua Borges Lagoa, 913, $1^{\circ}$ andar, Vila Clementino | São Paulo - SP - Brasil | CEP 04038-032 | Tel.: (11) 5571-0804 | E-mail: fpicchi@lean.org.br

\section{Ambiente Construído}

Revista da Associação Nacional de Tecnologia do Ambiente Construído

Av. Osvaldo Aranha, $99-3^{\circ}$ andar, Centro

Porto Alegre - RS - Brasil

$$
\text { CEP } 90035-190
$$

Telefone: +55 (51) 3308-4084

www.seer.ufrgs.br/ambienteconstruido www.scielo.br/ac

E-mail: ambienteconstruido@ufrgs.br 